\title{
La Torre inclinada de Pisa. Estructura, materiales de construcción e intervenciones de refuerzo
}

\section{The leaning Tower of Pisa. Structure, building materials and reinforcement interventions}

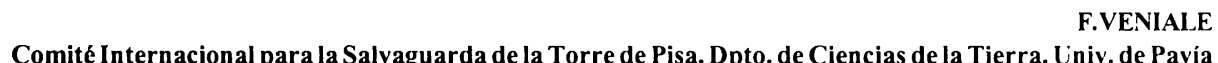

Fecha de recepción: 9-10-99

Fecha de aceptación: 24-01-00

ITAIIA

\section{RESUMEN}

Se ha realizado un exhaustivo estudio de diagnosis de la Torre inclinada de Pisa, con el fin de completar todo el conocimiento existente en torno a la estructura, condiciones mecánicas y procesos de alteración de los materiales de construcción, para proponer la terapia más correcta de intervención, ya sean éstas temporales o definitivas.

Las intervenciones ya realizadas o en fase de ejecución consisten en: (i) cables de acero ligeramente tensados rodeando la Torre, (ii) barras interiores tensadas y/o pasivadas, y (iii) relleno con una lechada de cemento con aditivo, especialmente preparado para tal fin.

El presente trabajo no se centrará en las restauraciones ni en las intervenciones geotécnicas realizadas para reducir la progresiva inclinación y estabilizar el sistema de cimentación de la Torre.

\section{SUMMARY}

An exhaustive diagnosis of "anatomy, physiology and pathology" of the masonry body of the leaning Tower of Pisa has been carried out with the aim of integrate the knowledge of the structure features, mechanical conditions and decay processes of the building materials, necessary for correctly managing the therapy, temporary and definitive interventions.

The interventions already or being implemented consist of: (i) outer circular slightly stressed steel tendons, (ii) inner stressed and/or passive strainless bars, and (iii) grouting by a specially devised cement admixture.

The paper will not be dealing with "materic" restoration works, and geotechnical interventions for reducing the progressive tilting and stabilizing the foundation/subsoil system of the Tower.

\section{INTRODUCCIÓN}

La Torre inclinada de Pisa ("Campanile" = Campanario) forma parte de un complejo arquitectónico conocido como "Piazza dei Miracoli", que incluye la Catedral ("Duomo"), el Baptisterio y el Cementerio Monumental, declarado Patrimonio de la Humanidad por la UNESCO, y visitado cada año por millones de turistas.

\section{INTRODUCTION}

The "leaning" Tower of Pisa ("Campanile" = belltower) is part of the architectural complex called "Piazza dei Miracoli" (Wonder Square) including the Cathedral ("Duomo"), the Baptistry and the Monumental Cemetery, which has been declared Humanity Heritage Site by UNESCO. This site is visited by millions of tourists every year. 
El estado de la Torre es un reto muy serio, no sólo porque cada vez se inclina más (alcanzando en nuestros días un valor de $5^{\circ} 30^{\prime}$ ) sino también por el peligro de un repentino colapso de la estructura. Como medida de precaución la Torre fue cerrada a los visitantes en 1989.

En 1990 el Gobierno Italiano nombró un Comité Internacional con la finalidad de salvaguardar la Torre. Por el amplio espectro de tareas a abordar, el Comité fue concebido como un cuerpo multidisciplinar con expertos en historia del arte, materiales de construcción y restauración, ingenieros de estructuras y geotécnicos.

Los estudios que se llevaron a cabo tuvieron como fin el conocimiento de los escenarios que rodean al monumento, así como la toma de decisiones en intervenciones temporales o permanentes enfocadas hacia el aumento de la seguridad con respecto al colapso y derrumbe de la Torre. Mientras tanto, fueron desarrollados de conceptos adecuados para intervenir en la restauración arquitectónica.

Desde el punto de vista de los materiales, el cuerpo central de la Torre es débil. Esto, unido a las características de la estructura y a la inestabilidad del sistema cimientos/subsuelo, hace que la inclinación aumente las tensiones a compresión en el lado sur (precisamente hacia el que se inclina) allí donde se localizan preferentemente los daños mecánicos en los materiales que conforman el edificio.

Con el fin de llegar a conseguir el refuerzo de la fábrica, las investigaciones preliminares se dirigieron hacia la consideración de diversos aspectos: naturaleza y propiedades físico-mecánicas de los materiales de construcción, y resistencia a la carga de las zonas más debilitadas de la estructura.

Tras un ensayo preliminar, fueron previstas una serie de intervenciones temporales y permanentes, algunas de ellas ya en marcha, con el fin de reforzar el cuerpo de la Torre. Más adelante se verán en detalle.

\section{HISTORIA DE LA CONSTRUCCIÓN}

Las 8 plantas de la estructura de la Torre (Figura 1) fueron construidas sobre un cilindro hueco ("canna") rodeado por 6 logias con columnas, que emerge desde la base ("tamburo"), reposando en los cimientos. $\mathrm{La}$ cámara que encierra el campanario en la parte superior de la estructura se conecta con la planta baja a través de una escalera de caracol situada en el cuerpo de fábrica anular $(1,2)$
The safety of the Tower is in serious jeopardy not only because of the continuously increasing inclination (reaching nowadays the alarming value of $5^{\circ} 30^{\prime}$ ) but also because of the danger of an almost instantaneous structural collapse of the masonry. Owing to the risk of failure, the Tower was closed to visitors in 1989.

An international Committee was appointed by the Italian Government in 1990 as a special authority for safeguarding the Tower. Because of the broad spectrum of the taskes envisaged, the Committee was conceived as a multidisciplinary body with experts of history of art, construction materials and restoration, structural and geotechnical engineering.

Studies have been carried out aimed to completing the knowledge of the scenarios threatening the monument, and to reach decisions on the temporary and permanent interventions to be implemented for improving the safety margin with respect to structural collapse and overturning of the Tower. Meantime, work has started to developing comprehensive guidelines for the architectural "materic" restoration.

The masonry body suffers weaknesses linked to the structure features and to the foundations/subsoil (in)stability. In fact, the inclination increases the compressive stresses at the South side (tilt direction) where the mechanical damages of the building materials are mainly located.

In order to achieve a reinforcement of the masonry, preliminary investigations have been carried out considering various aspects: nature and physicomechanical properties of the building materials, and loading strength of the weakest parts of the masonry structure.

After preliminary tests, a series of temporary and permanent interventions have been envisaged (partly already implemented) for the reinforcement of the masonry body: details are reported in this paper.

\section{CONSTRUCTION HISTORY}

The 8-storey structure of the Tower (Figure 1) is made up of a hollow cylinder ("canna") surrounded by 6-loggias with columns, emerging from the base ("tamburo"), resting on the foundations. The bell-chamber topping the structure is connected to the ground floor through a spiral staircase inside the annular masonry body $(1,2)$. 




Estructura de la mamposteria Masonry structure

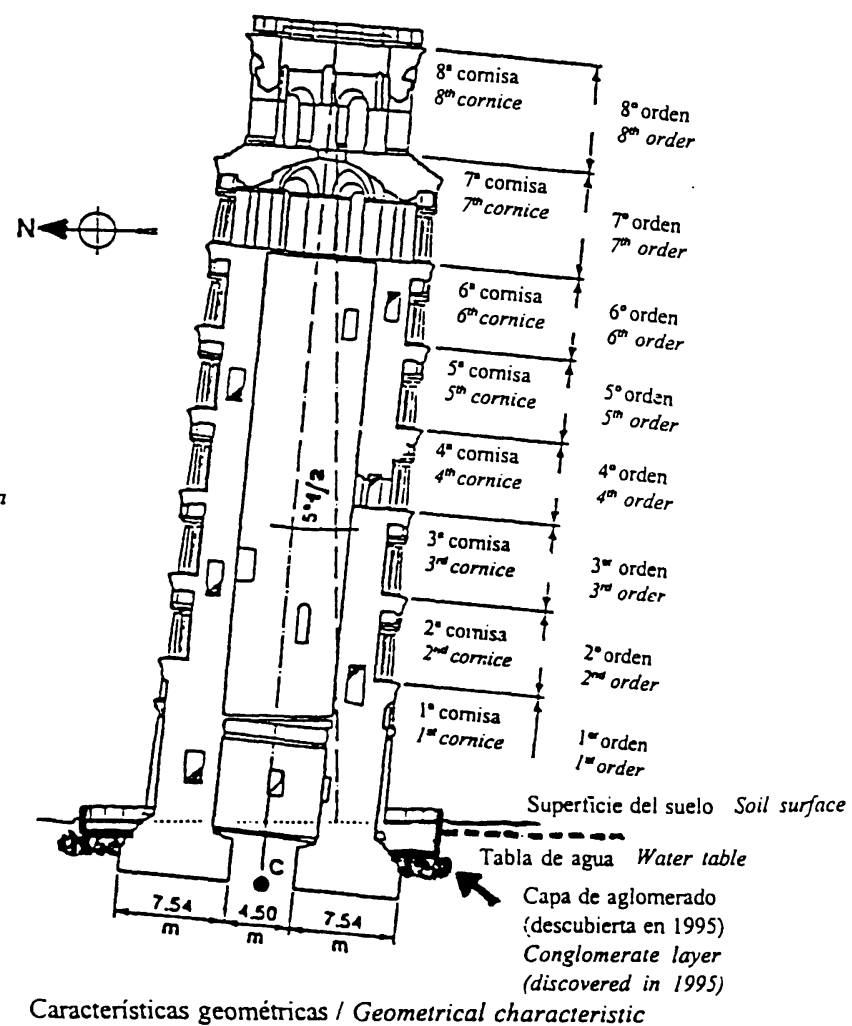

Altura total / Total height Diametro exterior de los cimientos anulares Outer diameter of the annular foundations Diametro interior de los cimientos anulares Inner diameter of the annular foundations Presión de los cimientos (en término medio) Average foundations pressure

Inclinación actual / Present inclination Altura del centro de gravedad / Height of the centre of gravity

(A partir del plano de cimientos)/(Above the foundation plane)
Figura 1.- La Torre inclinada de Pisa.

Figure 1.- The leaning Tower of Pisa.
The cylinder structure was constructed using the so-called "infill" tecnique (Figure 2), consisting of "3-leaves" elements: the internal and external stone facing walls, and the core made of a rubble concrete (rock fragments, gravel and sand cemented with a lime mortar). The masonry is made up of various structural and architectural elements:

\section{foundations}

32.400 stone blocks ("bozze" = ashlars) of the external and internal facing walls

" "infill" material (core) of the cylinder body

180 columns of the 6 loggias (30 in each order)

15 half-columns of the base

12 columns of the bell-chamber

. bases and capitals of the columns 


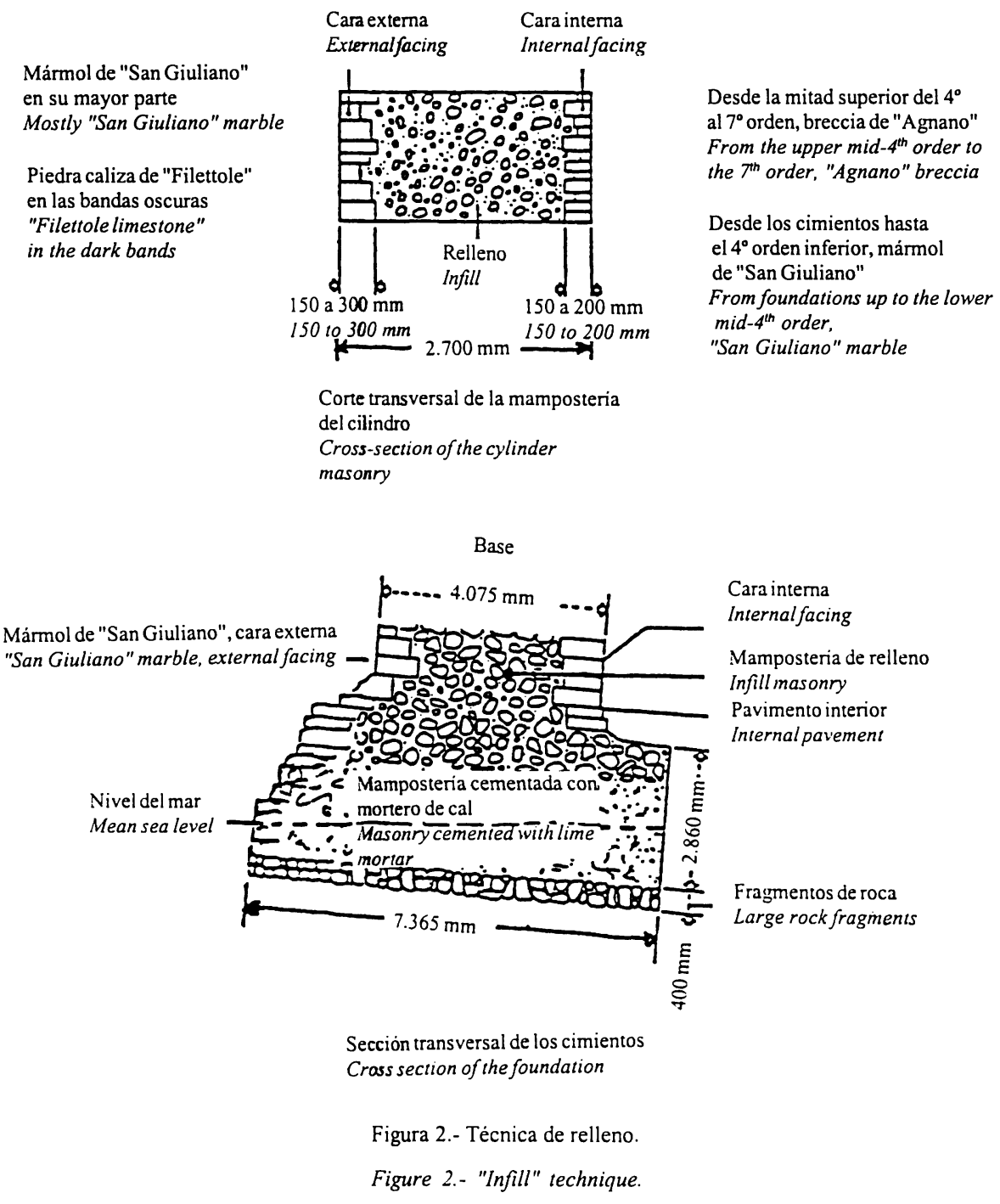

. arcos, volutas y cornisas de las logias y del campanario

. marcos de las puertas y ventanas

. 293 escalones, muros y techos de la escalera interior . bandas oscuras ornamentales de la fachada exterior y del campanario.

La construcción se inició en 1173, extendiéndose hasta 1178. El trabajo se interrumpió prácticamente en la mitad de la cuarta planta (Figura 3), continuándose un siglo después (1272). A los 6 años estaban prácticamente concluidos (séptima cornisa), excepción hecha del campanario. En 1278 la construcción volvió a interrumpirse, quizá a causa de un excesivo asentamiento e inclinación. El campanario fue añadido a la Torre entre 1360 y 1370.

Fue, en efecto, durante la segunda fase de su construcción cuando la torre empezó a inclinarse progresivamente hacia el sur (ver Tabla 1); sin embargo, durante la primera fase de la construcción, la arches, vaults and ledges of the loggias and bellchamber

- posts of the doors and windows

293 steps, walls and ceiling of the inner staircase . dark ornamental bands of the external facing and bell-chamber.

The construction began in 1173 and progressed steadily until 1178, reaching about the middle of 4 th order (Figure 3) when the work was interrupted. It was resumed only a century later (1272) and after 6 years it had almost reached completion (7th cornice), except for the bell-chamber. In 1278 the construction was again interrupted, perhaps as a result of excessive settlement and tilt. Only between 1360 and 1370 was the bell-chamber added to the Tower.

It was during the 2 nd construction stage that the tilting toward South occurred, progressively increasing (see Table 1); whereas, during the 1st construction stage the Tower remained essentially 


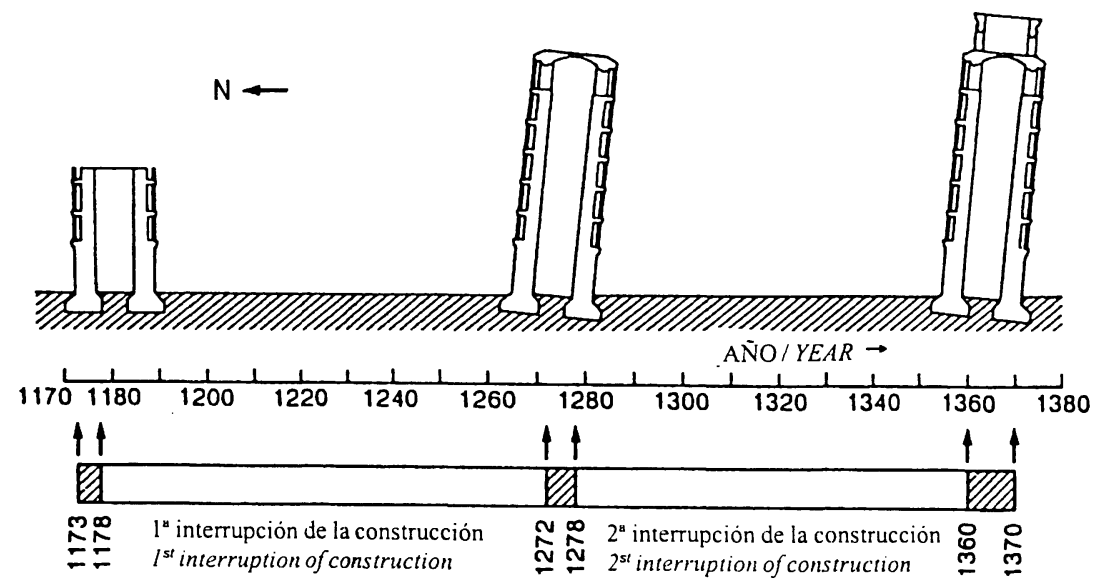

Figura 3.- Historia de la construcción.

Figure 3.- History of the construction.

TABLA 1 (TABLE 1$)$

Peso e inclinación según los años (Weight and rigid tilt versus time)

\begin{tabular}{|c|c|c|c|}
\hline Año (Year) & $\begin{array}{c}\text { Peso (Weight) } \\
\text { (MN) }\end{array}$ & $\begin{array}{l}\text { Inclinación } \\
\text { (Tilt) }\end{array}$ & \\
\hline $\begin{array}{c}(1173)-1178 \\
(1272)-1278 \\
1285 \\
1360-1370 \\
1550 \\
1758 \\
1817\end{array}$ & $\begin{array}{c}94,80 \\
137,28 \\
" \\
144,53 \\
" \\
" \\
"\end{array}$ & $\begin{array}{c}--- \\
0^{\circ} 06^{\prime} 11^{\prime \prime} \\
1^{\circ} 06^{\prime} 44^{\prime \prime} \\
1^{\circ} 36 ’ 39^{\prime \prime} \\
4^{\circ} 41^{\prime} 07^{\prime \prime} \\
4^{\circ} 49^{\prime} 50^{\prime \prime} \\
5^{\circ} 06^{\prime} 11^{\prime \prime}\end{array}$ & $\begin{array}{c}\text { ler nivel (1st stage) } \\
2^{\circ} \text { nivel (2nd stage) } \\
\text { campanario (bell-chambre) }\end{array}$ \\
\hline \multicolumn{4}{|c|}{ mediciones sistemáticas (sistematic measurements) } \\
\hline $\begin{array}{l}1911 \\
1978\end{array}$ & $"$ & $\begin{array}{l}5^{\circ} 14^{\prime} 46^{\prime \prime} \\
5^{\circ} 21^{\prime} 28^{\prime \prime}\end{array}$ & $\begin{array}{l}\text { mediciones sistemáticas } \\
\text { (sistematic measurements) }\end{array}$ \\
\hline \multicolumn{4}{|c|}{ medidas realizadas por el Comité (measurement carried out by the Committe) } \\
\hline $\begin{array}{l}1990 \\
1993 \\
1999\end{array}$ & n & $\begin{array}{l}5^{\circ} 28^{\prime} 09^{\prime \prime} \\
5^{\circ} 33^{\prime} 27^{\prime \prime} \\
5^{\circ} 32^{\prime} 51^{\prime \prime}(*)\end{array}$ & $\begin{array}{l}\text { antes de la aplicación del } \\
\text { contrapeso } \\
\text { (prior to counter wight } \\
\text { implement) }\end{array}$ \\
\hline
\end{tabular}

$\left({ }^{*}\right)$ La reducción de la inclinación se debe al contrapeso (de aproximadamente 700 toneladas) aplicado en 1993-4 por encima de los cimientos (zona norte); se lograron posteriores reducciones debidas a las excavaciones realizadas entre 1998 y 99 bajo los cimientos. (The tilt reduction is due to the counterweight (about 700 tons) implemented in 1993-4 onto the northside of the foundations; further reduction has been obtained by the preliminary soil under excavation (1998-99).

Torre permaneció completamente vertical. En la actualidad, puede apreciarse una inclinación hacia el Norte, existiendo una variación en el espesor de los bloques de piedra que forman la parte frontal de los muros ya que, durante la construcción, debieron vertical. Actually, a very slight inclination toward North could be deduced from the thickness variation of stone blocks constituting the facing walls; in fact, adjustements of the tilting have been made during 
realizarse, posiblemente, algunos ajustes en la inclinación (Figura 4). Las reglas seguidas por los constructores fueron, con toda seguridad, las siguientes:

(i) intentar que las capas de mampostería se mantuvieran horizontales, y (ii) hacer que el eje central de la Torre se mantuviera vertical. Asimismo, el campanario fue construido más vertical sobre la estructura cilíndrica: en la parte Norte hay cuatro escalones, desde la séptima cornisa hasta el suelo del campanario, mientras que en la zona Sur son seis. El resultado fue la conocida "banana", por su forma curvada.

Otra estructura importante en la Torre es el hueco ("catino") excavada en 1838 (3) con el fin de dejar al descubierto los anclajes de las columnas y la base de los escalones, por entonces cubiertos a consecuencia del asentamiento. El suelo del "catino" se reforzó con 80-90 cm de una capa de conglomerado espeso (Figura 1), en parte colocado durante la intervención Gherardesca, y en parte durante los trabajos de the construction (Figure 4). The rules followed by the masons could had been:

(i) try to keep horizontal the masonry layers; (ii) bring back vertically the centre-line of the Tower. Also the bell-chamber was set up noticeably more vertical onto the cylinder structure: on the North side there are 4 steps from the 7 th cornice up to the floor of the bell-chamber, while on the South side the steps are 6. The result was the so-called curved "banana" -like shape.

Another important structural part of the Tower is the basin ("catino") excavated in 1838 (3) with the purpose to expose the column plinths and base steps, at that time covered as a consequence of the settlement. The "catino" floor is reinforced with a $80-90 \mathrm{~cm}$ thick conglomerate layer (Figure 1) partly set up during Gherardesca intervention, and partly



Figura 4.- Corrección de la estructura de mamposteria para ajustar la inclinación (ver texto).

Figure 4.- Correction of the masonry structure for adjusting the inclination (see text). 
"relleno" con lechada en los cimientos, llevados a cabo en 1935-38 (ver Figura 5). Este aglomerado estuvo unido a los cimientos a través de unas barras huecas de acero usadas para sellar el "catino". No existía documentación alguna acerca de esta capa de conglomerado hasta que fue descubierta en 1995 cuando se procedió a la congelación del subsuelo de la Torre. Este trabajo fue preliminar a la construcción de un anillo de cemento alrededor de los cimientos, como parte de un proyecto para insertar en el subsuelo, en la zona Norte, 10 anclajes, con una profundidad de $60 \mathrm{~m}$, con el fin de ayudar a mantener la estabilidad de la Torre. El proyecto fue suspendido, a la espera de ver los resultados de la excavación del subsuelo en la zona Norte, ejecutada para reducir la inclinación de la Torre. during the grouting of the foundations works performed in 1935-38 (Figure 5). The conglomerate layer also resulted connected to the foundations by a number of steel pipes used for sealing (cement inyection) the "catino" from water inflow. No documentation existed about such conglomerate layer that was discovered in 1995 by borings implemented for freezing the underneath subsoil. This work was preliminary to the construction of a reinforced cement ring around the foundations, as part of the project to insert in the subsoil, in North side, 10 deep anchors $(60 \mathrm{~m})$ with the aim to maintain the Tower stable. This project is at the moment suspended, waiting for the results of the subsoil excavation under the North side of the foundations being implemented for reducing the inclination of the Tower.

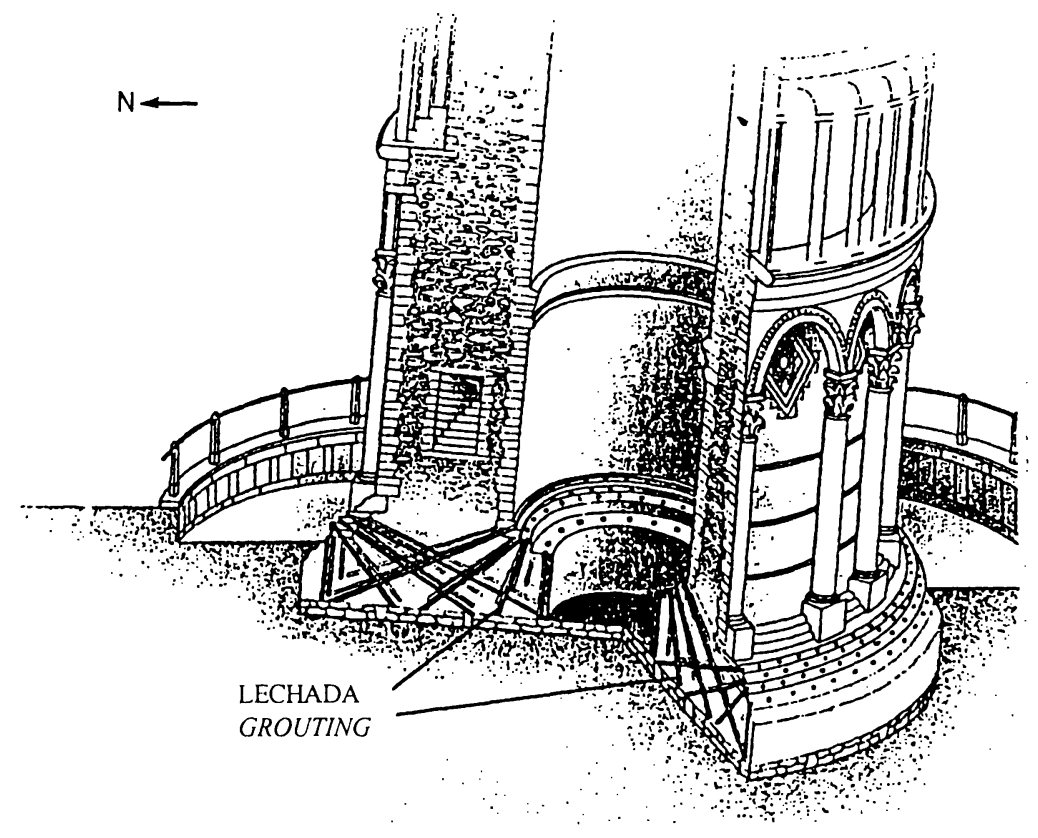

Figura 5.- Lechada de cemento en los cimientos realizada entre 1935-38.

Figure 5.- Cement grouting of the foundations performed in 1935-38.

\section{MATERIALES DE CONSTRUCCIÓN}

Se identificaron diversos litotipos como materiales utilizados en la construcción de la Torre $(4,5)$.

\section{Piedras originales:}

. Mármol de San Giuliano, la piedra más utilizada en la construcción de la Torre: caras interior y exterior de los muros de los cimientos y de la estructura cilindrica, columnas y otros elementos estructurales de las logias y también en el campanario.

\section{BUILDING MATERIALS}

Various stone lithotypes have been identified as materials used for the construction of the Tower (4, 5)

\section{Original stones:}

. San Giuliano marble, the most abundant stone used in the Tower masonry: external and internal facing walls of foundations and cylinder structure, columns and other architectural elements of the loggias, and bell-chamber. 
. Breccia de Agnano, utilizada únicamente en la segunda fase de la construcción, principalmente en la cara interna de los muros del cilindro.

- Piedra caliza gris oscuro de Filletole, utilizada sobre todo en las bandas oscuras ornamentales de la fachada.

. Cuarcita "Verrucano", utilizada principalmente para formar los marcos de las puertas y los arquitrabes.

. Breccia de Caprona, utilizada rara vez como material original. En épocas posteriores se usó para reemplazar algunos capiteles y bases de las columnas.

. Piedra caliza "Selcifero", presente únicamente como gravas en el hormigón para relleno.

. Calcarenita "Panchina", encontrada esporádicamente en los áridos del hormigón de relleno y en la cara interna de los muros del cilindro. Probablemente se utilizó para formar las volutas de las logias, que en realidad se encuentran protegidas por revoco.

- Granodiorita de la isla de Elba, utilizada en algunas de las medias columnas de la base (primera planta).

\section{Piedras utilizadas en las restauraciones:}

. Mármoles de la región Apuana (Carrara blanco y sus variedades), explotados en las canteras que rodeaban la famosa localidad, a $50 \mathrm{~km}$ al norte de Pisa. Se utilizaron únicamente como material de sustitución del mármol de San Giuliano en muchos elementos arquitectónicos, sobre todo para las columnas (en algunos casos hasta en un $70 / 80 \%$ ). La variedad gris ("bardiglio") se utilizó para sustituir las bandas ornamentales dañadas, en las que originalmente se había usado piedra caliza gris oscuro de Filettole. En la referencia (6), se detallan las sustituciones realizadas con estos marmoles.

. Granito, se empleó para reemplazar pequeñas zonas en las medias columnas de granodiorita.

- Serpentinita, diminutos fragmentos de este litotipo sutituyeron la piedra caliza gris oscura de Filettole.

. Arenisca "Macigno", se utilizó en las escaleras, de manera muy limitada.

Para consultar mapas detallados de la distribución de los litotípos, se recomienda la referencia (7).

La mayor parte de las piedras procedían de canteras próximas, situadas en los montes Pisanos y en el área de Oltre Serchio; otras fuentes tienen la calcerenita "Panchina" (procedente de un área próxima a Livorno, a $20 \mathrm{~km}$ al sur de Pisa) y la granodiorita (de la isla de Elba, a una distancia de, aproximadamente, $80 \mathrm{~km}$ ). Algunos litotipos (granito, serpentinita y arenisca "Macigno"), utilizados en muy pequeñas cantidades, provenían de fuentes indeterminadas. El material "de relleno" de la estructura cilíndrica y de los cimientos está compuesto por fragmentos de varios litotipos que son los que figuran en la parte
Agnano breccia, only used during the 2nd construction stage, mainly as internal facing wall of the cylinder.

- Filettole dark-grey limestone, mostly used as dark ornamental bands of the façade.

. "Verrucano" quartzite, mostly used to form door-posts and architraves.

. Caprona breccia, rarely used as original material; further, for the replacement of some column capitals and bases.

"Selcifero" (cherty) limestone, present only as "infill" concrete rubble.

- "Panchina" calcarenite, found only sporadically in the "infill" concrete rubble, and on the internal facing wall of the cylinder; it is probably abundant in the plastered-over vaults of the loggias.

. Granodiorite from Elba island, used for some half-columns of the base (1 ${ }^{\text {st }}$ order).

\section{Substitution stones:}

. "Apuanian" marbles (white Carrara and its varieties) have been exploited in the quarries around the famous locality, about $50 \mathrm{~km}$ northward of Pisa; they were only used as replacement materials for many architectural elements, mainly columns (in some orders until 70$80 \%$ ) originally in San Giuliano marble. The grey variety ("bardiglio") was used for replacing damaged ornamental bands, originally in Filettole dark-grey limestone. A detailed mapping of the replacements by Apuanian marbles is given in (6).

. Granite replaces small parts of granodiorite halfcolumns of the base.

- Serpentinite minute fragments substitute Filettole dark-grey limestone.

"Macigno" sandstone is very limited in the stairway.

For detailed mappings of the lithotype distribution, refer to (7)

The stones mostly come from the nearby quarries located in the Pisani and Oltre Serchio Mts areas; other sources have the "Panchina" calcarenite (from the area around Livorno, about $20 \mathrm{~km}$ South of Pisa), and the granodiorite (from the Elba island, at a distance of about $80 \mathrm{~km}$ ). Some lithotypes (granite, serpentinite and "Macigno" sandstone) used in very limited quantity are of undetermined sources. The "infill" material of the cylinder structure and foundations is composed of fragments of the same lithotypes which make up the facing walls, and of 
exterior de los muros, además por grava y arena, todos cementados con mortero de cal. Cabe destacar que la piedra caliza "Selcifero" es más abundante en los cimientos, mientras que los fragmentos de mármol de San Giuliano son más abundantes en la zona central del cilindro correspondiente a la primera fase de la construcción; finalmente, en la parte superior de la Torre (segunda fase de la construcción), hay un significativo contenido de breccia de Agnano. La proporción media mortero/árido en el hormigón es prácticamente uniforme en todo el cuerpo de la Torre: el contenido de mortero es de aproximadamente $1 / 3$ en volumen. La composición del mortero varía en los diferentes niveles y etapas de la construcción, incluso en un mismo nivel. Las diferencias se encuentran en la granulometría del árido (arena), en la relación ligante/ árido, y en el grado de decarbonatación (8).

Los áridos arenosos proceden de los sedimentos de los ríos Serchio y Arno que atraviesan Pisa. En los cimientos se utilizó un árido grueso, mientras que áridos más finos fueron empleados en la elaboración de morteros en las zonas superiores de la mampostería de la Torre. El contenido de carbonato en la matriz aumenta según se incrementa la altura de los niveles de la estructura.

El ligante del mortero está constituido básicamente por una calcita de grano fino, ocasionalmente asociada a aragonita y vaterita, con textura dishomogénea (presencia de microaglomerados). Análisis por microsonda evidencian su carácter hidraúlico (importantes cantidades de $\mathrm{SiO}_{2} \mathrm{y}_{2} \mathrm{Al}_{3}$ ). Silicatos cálcicos hidratados se detectaron en el mortero de los cimientos, probablemente adulterado por la inyección de cemento efectuada en 1935-38.

En la Tabla 2 se presentan los parámetros físicos y mecánicos representativos de los principales litotipos, comparados con aquellos de morteros y materiales de "relleno". Otras características diferenciales de los morteros se encuentran en la Tabla 3.

\section{CONDICIONES DE CONSERVACIÓN- ALTERACIÓN DE LOS MATERIALES DE CONSTRUCCIÓN}

Todos los materiales de construcción han sufrido -y están sufriendo- en la actualidad diversos tipos de daños mecánicos, físicos, químicos y biológicos; su situación real viene condicionada por su localización dentro de la estructura y la exposición a los agentes externos (lluvia, viento y radiaciones solares).

Por lo tanto se consideró necesario, para una correcta planificación de la restauración, tener un amplio gravel and sand, all cemented by a lime-mortar Noteworthy, the "Selcifero" (cherty) limestone is prevailing in the rubble of the foundations, whereas San Giuliano marble fragments are most frequent in the core of the cylinder corrisponding to the $1^{\text {st }}$ construction stage; in the upper part of the masonry ( $2^{\text {nd }}$ construction stage) there is a significant content of Agnano breccia. The volume ratio of mortarl rubble elements is roughly uniform through the core of the masonry body: the mortar content is about 1/3 by volume. The mortar composition is varying with regard to different levels and stages of construction, and even to a single layer. The differences are concerning the granulometry of sand inert, binder/ inert ratio, degree of carbonation (8).

The sand components of the inert are quite similar to the sediments of the Serchio and Arno rivers crossing Pisa. A coarser sand was used in the foundations, while finer sands were employed in the preparation of mortars for the masonry upper parts. The carbonate amount of the matrix increases towards the upper levels of the masonry.

The mortar binder consist mainly of fine-grained calcite, occasionally associated to aragonite and vaterite, with dishomogeneous texture (presence of clots). Detailed microprobe chemical analyses have evidenced a hydraulic character (relevant amounts of $\mathrm{SiO}_{2}$ and $\mathrm{Al}_{2} \mathrm{O}_{3}$. Hydrated Ca-silicates are present in the foundation mortar, probably adulterated by cement injection performed in 1935.

Representative physical and mechanical parameters of the main lithotypes, compared with those of mortars and "infill" materials are given in Table 2; further characteristics differentiating the mortars are in Table 3.

\section{CONSERVATION-DECAY CONDITIONS OF THE BUILDING MATERIALS}

All of the building materials have been and are still suffering various kinds of mechanical, physical, chemical and biological damages; their aspects are also linked to the location within the masonry structure, and to the exposure to weathering agents (rain, wind and sun radiation).

A full knowledge of the "state-of-health" of the Tower masonry was thus considered necessary for 
TABLA 2 (TABLE 2)

Parámetros físicos de los principales tipos de piedra y materiales de relleno (Physical parameters of the main stone types and "infill" materials)

\begin{tabular}{|c|c|c|c|c|c|}
\hline Litotipo (Lithotype) & $\begin{array}{l}\text { Peso unitario seco } \\
\text { (Unit weight dry) } \\
\quad\left(\mathrm{g} / \mathrm{cm}^{3}\right)\end{array}$ & $\begin{array}{l}\text { Coeficiente de imbibición } \\
\text { (Imbibition coefficient) } \\
\text { peso \% (weight \%) }\end{array}$ & $\begin{array}{c}\text { Resistencia a la } \\
\text { compresión } \\
\text { (Compressive strenght) } \\
\text { (MPa) } \\
\end{array}$ & $\begin{array}{l}\text { Resistencia a la tensión } \\
\text { (Tensile strenght) } \\
\text { (MPa) }\end{array}$ & $\begin{array}{l}\text { Módulos de elasticidad } \\
\text { (Elasticity modulus) }\end{array}$ \\
\hline $\begin{array}{l}\text { Mármol de S. Giuliano } \\
\text { (S. Giulliano marble) }\end{array}$ & $\begin{array}{c}(2,64-2,46) \\
2,65 \\
\end{array}$ & $\begin{array}{c}(0,10-0,17) \\
0,41 \\
\end{array}$ & $\begin{array}{c}(110-190) \\
130-150 \\
\end{array}$ & 4 a $8(4$ to 8$)$ & 70.000 a 90.000 \\
\hline $\begin{array}{l}\text { Breccia de Agnano } \\
\text { (Agnano breccia) }\end{array}$ & $\begin{array}{l}2,31-2,46 \\
2,00-2,74\end{array}$ & $\begin{array}{c}1,64-2,20 \\
\text { n.d. }\end{array}$ & $\begin{array}{l}\text { n.d. } \\
\text { n.d. }\end{array}$ & $\begin{array}{l}\text { n.d. } \\
\text { n.d. }\end{array}$ & $\begin{array}{l}\text { n.d. } \\
\text { n.d. }\end{array}$ \\
\hline $\begin{array}{c}\text { Piedra caliza gris oscuro' } \\
\text { deFilettole } \\
\text { (Filettole dark-gray } \\
\text { limestone) } \\
\end{array}$ & $2,67-2,68$ & n.d. & $(130-200)$ & n.d. & n.d. \\
\hline $\begin{array}{l}\text { P. Piedracaliza "Selcifero" } \\
\text { (Selciferous limestone) }\end{array}$ & 2,70 & 0,25 & n.d. & n.d. & n.d. \\
\hline $\begin{array}{c}\text { Cuarcita "verrucano" } \\
\text { ("Verrucano" quartzite) }\end{array}$ & 2,60 & 0,69 & n.d. & n.d. & n.d. \\
\hline $\begin{array}{l}\text { Calcarenita "panchina" } \\
\text { ("Panchina" calcarenite) }\end{array}$ & $\begin{array}{l}1,64-1,71 \\
1,68-1,76 \\
\end{array}$ & $18-19$ & n.d. & n.d. & n.d. \\
\hline $\begin{array}{l}\text { Materiales de relleno } \\
\text { (Infill material) }\end{array}$ & n.d. & n.d. & $4-8$ & $0,3-1,3$ & 5.000 a 7.500 \\
\hline
\end{tabular}

I.os datos entre ( ) fueron tomados de los estudios previamente realizados; todos los demás pertenecen al presente estudio.

l.os da tos en "cursiva" son muestras frescas tomadas en las canteras; todas las demás proceden de las muestras recogidas en la mamposteria de la Torre.

n. $\mathrm{d}$. $=$ no determinados.

Data between ( ) are from previous studies; all the other from present study.

Data in italics are fresh samples collected in the source quarries; all the others are from samples collected in the Tower's masonry.

n. $d .=$ not determined. 
TABLA 3 (TABLE 3)

Parámetros físicos y composición simplificada (así como tamaño del árido) en los morteros

(Physical parameters and semplified composition (and grain-size) of mortars)

\begin{tabular}{|c|c|c|c|c|c|c|c|c|}
\hline \multirow{3}{*}{$\begin{array}{l}\text { Etapa de construcción } \\
\text { (Stage of construction) }\end{array}$} & \multirow{3}{*}{$\begin{array}{c}\text { Peso unitario } \\
\text { seco }\left(\mathrm{g} / \mathrm{cm}^{3}\right) \\
(\text { Unit weight } \\
\left.\text { dry }\left(\mathrm{g} / \mathrm{cm}^{3}\right)\right)\end{array}$} & \multirow{3}{*}{$\begin{array}{l}\text { Coeficiente de } \\
\text { imbibición } \\
\text { (peso \%) } \\
\text { (Imbibition } \\
\text { coefficient } \\
\text { (weight \%)) }\end{array}$} & \multicolumn{3}{|c|}{ Componentes (Components) } & \multirow{2}{*}{\multicolumn{3}{|c|}{$\begin{array}{l}\text { Distribución por tamaño }(\mathrm{mm}) \\
\text { (Grain size distribution }(\mathrm{mm}) \text { ) }\end{array}$}} \\
\hline & & & \multicolumn{2}{|c|}{$\begin{array}{l}\text { Inerte arenoso } \\
\text { (Sandy inert) }\end{array}$} & \multirow{2}{*}{$\begin{array}{c}\begin{array}{c}\text { Matriz ligante } \\
\text { (Binding } \\
\text { matrix) }\end{array} \\
\% \%\end{array}$} & & & \\
\hline & & & $\% \mathrm{~N}-\mathrm{C}$ & $\% \mathrm{C}$ & & $\varnothing 0,25$ & $0,25>\varnothing<0,50$ & $\varnothing>0,50$ \\
\hline $\begin{array}{l}1^{\text {a }} \text { ETAPA } \\
\text { (1st STAGE) } \\
\text { Cimientos* } \\
\text { (Foundations)* }\end{array}$ & $\begin{array}{r}1,6-1,7 \\
(2,25)\end{array}$ & $\begin{array}{r}19,21 \\
(4)\end{array}$ & $43-49$ & $\begin{array}{l}8-12 \\
(16)\end{array}$ & $\begin{array}{l}46-50 \\
(35)\end{array}$ & $\begin{array}{l}19-21 \\
(13)\end{array}$ & $\begin{array}{l}28-32 \\
(21)\end{array}$ & $\begin{array}{l}53-57 \\
(66)\end{array}$ \\
\hline $\begin{array}{l}\text { Desde el primer nivel (base) hasta } \\
\text { la mitad del } 4^{\circ} \text { nivel } \\
\text { (From } 1^{s t} \text { order (base) to } \\
\text { middle } 4^{\text {th }} \text { order) }\end{array}$ & $1,5-1,8$ & $\begin{array}{c}19-21 \\
(15)(25)\end{array}$ & $\begin{array}{c}40-43 \\
(55)(61)\end{array}$ & $\begin{array}{l}8-12 \\
(17)\end{array}$ & $\begin{array}{c}45-49 \\
(34)\end{array}$ & $\begin{array}{c}16-19 \\
(14)(35)\end{array}$ & $\begin{array}{c}40-45 \\
(27)\end{array}$ & $\begin{array}{c}30-34 \\
(23)(42)(57)\end{array}$ \\
\hline $\begin{array}{l}2^{\text {a }} \text { ETAPA } \\
\text { (2nd } S T A G E) \\
\text { Desde la mitad del } 4^{\circ} \text { nivel hasta } \\
\text { cilindro } \\
\text { (From middle } 4^{\text {th }} \text { order to } \\
\text { cylinder) }\end{array}$ & 1,5 & $23-24$ & $35-39$ & $6-9$ & $52-59$ & $27-32$ & $52-54$ & $15-21$ \\
\hline $\begin{array}{l}\text { al } 7^{\circ} \text { nivel (voluta) } \\
\left.\left.\text { the } 7^{\text {th }} \text { order (vault) } t\right)\right)\end{array}$ & $\begin{array}{c}1,57 \\
(1,20)\end{array}$ & $\begin{array}{c}21-22 \\
(42)\end{array}$ & $\begin{array}{c}32-38 \\
(42)\end{array}$ & $\begin{array}{l}6-8 \\
(4)\end{array}$ & $\begin{array}{c}57-61 \\
(41)\end{array}$ & $\begin{array}{c}25-40 \\
(13)\end{array}$ & $44-45$ & $\begin{array}{c}16-26 \\
(41)\end{array}$ \\
\hline
\end{tabular}

${ }^{*}$ ) Algunos ejemplos fueron adulterados a través de inyecciones de cemento (1935)

$\mathrm{N}-\mathrm{C}=$ granos no carbonatos; $\mathrm{C}=$ granos de carbonatos

( ) Valores excepcionales

(*) Some samples were adultered by cement injection (1935)

$\overline{i .} \quad(N-C=$ non-carbonate grains; $C=$ carbonate grains $)$

() Exceptional values 
conocimiento sobre su estado de conservación. Con tal finalidad, se llevaron a cabo una serie de estudios multidisciplinares, tales como: revisión de su historia (9), documentación fotográfica, control fotogramétrico, mapa de los litotipos utilizados (7) y el estado de deterioro de los mismos (10); polución atmosférica (11) y micro-clima alrededor de la Torre (12); impacto de viento y movimientos sísmicos; monitorización continuada de los movimientos de la Torre y de las deformaciones de la estructura, así como una modelización de las condiciones de fatiga a través de elementos finitos 3-D. Además, se llevaron a cabo análisis y ensayos, tanto en laboratorio como in situ, con el fin de conocer el proceso de deterioro de la piedra y seleccionar los tratamientos para su conservación.

En un banco de datos, accesible a través del WEB http://torre.duomo.pisa.it, se ha recopilado una información clara y concisa al respecto, así como también en la pre-edición del volumen editado por el International Workshop "La restauración de la Torre Inclinada de Pisa: situación actual y futuro" presentado en Pisa (julio 1999) y publicado por el Comité Internacional para la salvaguarda de la Torre.

\section{PRODUCTOS DE DETERIORO}

Las piedras y los morteros han sufrido diversos procesos de deterioro, todavía activos en diferentes grados (10).

La alteración física tiene mucho que ver con causas naturales. Daños ocasionados en el mármol de San Giuliano por las variaciones de temperatura, sobre todo en la parte sur, han producido una masa de cristales de calcita sin conexiones intercristalinas (mármol “cocido"). Las abrasiones causadas por el viento y fenómenos de "pitting" han afectado a todas las piedras, sobre todo aquéllas que se encuentran en los cuadrantes Sur-Oeste, expuestas al fuerte viento àbrego. La proximidad del mar Tirreno ( 5 millas) y, por ello, la incidencia del rocío marino, producen una cristalización de $\mathrm{NaCl}$ y otras sales solubles (sobre todo sulfato de calcio) en la superficie de la piedra, ocasionando una disgregación de cristales de calcita similar a la del mármol "cocido".

El deterioro químico parece tener relación tanto con las causas naturales como con la polución antropogénica. La lluvia ácida (debida a la presencia de aniones $\mathrm{SO}_{4}{ }_{4}^{2-}, \mathrm{HCO}_{3}^{-} \mathrm{y} \mathrm{NO}_{3}^{-}$) es causa de la corrosión, disolución y eliminación de carbonato cálcico en las superficies expuestas, así como de la aparición de costras negras, donde el yeso aparece como el más correctly managing the restoration and reinforcement works. For such purpose, a series of multidisciplinary studies have been carried out: review of the historical background (9), photographic documentation, photogrammetric survey, mapping of lithotypes used (7) and of their decay by-products (10), atmospheric pollution (11) and micro-climate around the Tower (12), wind and sismic impact, continuos monitoring of the Tower movements and of the masonry structure distortions, 3-D finite element modelling of stress conditions. Furthermore, extensive in-situ and laboratory analyses and tests have been carried out on stone decay processes and conservative-protective treatments.

A comprehensive information has been collected in a data bank available on the $\boldsymbol{W E B}$ site http://torre.duomo.pisa.it. Further information is available, in the Pre-prints volume of the International Workshop "The restoration of the leaning Tower of Pisa: present situation and perspectives" held in Pisa (july 1999) published by the International Committee for the Safeguard of the Tower of Pisa.

\section{DECAY BY-PRODUCTS}

Stones and mortars have been involved by various kinds of decay processes, active in varying degree still nowadays (10).

The physical degradation in mostly related to natural causes. Temperature excursions, particularly marked on the South side, deeply damage the San Giuliano marble producing a mass of calcite crystals lacking intercrystalline connections ("baked" marble). Wind abrasion and pitting affect all the stones, particularly those of the South-West quadrants, exposed to the strong Libeccio wind. Marine spray from the nearby (5 miles) Tyrrhenian Sea brings about crystallisation of $\mathrm{NaCl}$ and other soluble salts (mostly Ca-sulphate) on the stone surface, causing disaggregation of calcite crystals similar to "baked" marble.

Chemical weathering seems to be related to both natural causes and anthropogenic pollution. Acid rains (due to the presence of, $\mathrm{SO}_{4}=\mathrm{HCO}_{3}^{-}$and $\mathrm{NO}_{3}^{-}$and anions) cause corrosion, dissolution and washing away of carbonate material on the exposed surfaces, and precipitation of black crusts, where gypsum appears as the most abundant by-product, diffused on all the 
importante producto de la alteración, disperso en aquellas superficies del monumento que no son lavadas por los frecuentes temporales. El yeso está presente en cantidades significativas incluso en espacios interiores, como la parte interna de la cara vista, tanto del cilindro como de la escalera. En estos lugares, parece tener conexión con las gotas de lluvia ácida producidas por la condensación de los componentes atmosféricos en espacios aislados. La presencia de yeso como producto en alteración en el mortero de relleno está indicando que éste está siendo atacado por ácido sulfúrico. Esto significa que existen importantes filtraciones de agua en la fábrica de la Torre (13), también evidenciadas por un depósito secundario de calcita de tipo "traventino" incrustado en los muros y techo de la escalera y de la superficie interna de la estructura cilíndrica.

Las pátinas de oxalato de cálcio esporádicamente encontradas en franjas estrechas de las superficies internas y externas de la Torre, pueden deberse principalmente a la transformación de los materiales utilizados en el pasado para los tratamientos de protección, y no producidos por el deterioro de las piedras, morteros y otros materiales.

Las pátinas coloreadas de verde y rojo que cubren las campanas de bronce y las abrazaderas de cobre, insertadas como juntas para los bloques de piedra y elementos arquitectónicos, o aplicadas como anillos de refuerzo en las columnas (extendiéndose con frecuencia sobre la superficie de las piedras adyacentes), están compuestas principalmente por atacamita (oxicloruro de cobre) y cuprita (óxido de cobre). También aparecen, aunque en menor cantidad, otros productos de alteración como el sulfato y nitrato de cobre en forma pseudo-cristalizada. La presencia de dichos componentes se explica por la existencia en el aire de una cantidad de $\mathrm{NaCl}$ procedente del ambiente marino. Sin embargo, la presencia de nitratos y sulfatos es indicativa de un aumento progresivo de la polución ambiental debida al hombre. Depósitos de polvo (formados principalmente por cuarzo y calcita asociados con granos finos de yeso cristalizado; y mica como componente minoritario) se encuentran por toda la cara interna de los muros y, en cantidad más reducida, por las zonas más resguardadas de la cara externa del mismo.

Otros depósitos superficiales son costras microostomatolíticas, pátinas y biofilms (14), en colores que van desde los blanquecinos a los prácticamente negros, pasando por naranjas y marrones. En la mayoría de los casos, se han separado de las superficies pétreas, produciendo un aspecto altamente descompuesto en los elementos arquitectónicos. En muchos casos éstas corresponden monument surfaces not washed by frequent runoff. Gypsum is present in significant amount even in internal spaces such as the inner cylinder facing wall and the staircase: in these locations, it seems to be connected with acid dew ensuing from condensation of atmospheric components in confined rooms. Even more worring is the presence of gypsum as a decay by-product of the "infill" mortar, indicating that a process of acid sulphatic attack is going on. This implies a significant water percolation just within the Tower masonry (13), which is also proved by the cospicuous secondary deposits of calcite (travertine like) encrusting walls and ceiling of the staircase, and the internal surface of cylinder structure.

Ca-oxalate patinas, sporadically found in narrow strips on both the external and internal surfaces of the Tower, are regarded as mostly due to the transformation of materials utilised in the past for protective treatments, and not produced by decay processes of stones, mortars and other materials.

Green-red coloured patinas covering the bronze bells and copper clamps, inserted sporadically as joints for stone blocks and architectural elements or applied as reinforcing rings to columns (they often extend out over the surface of adjacent stones), are mainly composed of atacamite ( $\mathrm{Cu}$-oxycloride) and cuprite (Cu-oxide), respectively; associated are also smaller amounts of other ill-defined phases, as $\mathrm{Cu}$ sulphate and Cu-nitrate. The presence of such compounds is explained by the wide distribution in the air of $\mathrm{Na}$-chloride borne from sea-spry.

However, the presence of nitrates and sulphates is indicative of progressively worsening man-made environmental pollution. Incoherent dust deposits (mainly made-up of quartz and calcite associated to fine-grained ill-crystalised gypsum; mica is a minor component) carpet almost all the internal facing walls and, less extensively, the more sheltered areas of the external facing wall.

\section{Other surface deposits are layered} microstomatolitic crusts, patinas and biofilms (14), ranging in colour from whitish to almost black, through orange and brown hues. In most of the cases, they are quite detached from stone surfaces, givin a highly decayed aspect to the architectural elements. Many occurences are colonised by endolithic microflora (lichens and fungii) which penetrates the stones through their 
a colonizaciones por microflora endolítica (líquenes y hongos) que penetra en la piedra a través de sus puntos débiles (zonas de intergrano y microfisuras) (15)

\section{INTERVENCIONES DE REFUERZO EN FÁBRICA}

A través de los siglos se han realizado tratamientos de protección y trabajos de mantenimiento en la Torre, lo que explica la sustitución de muchos de sus elementos y la gran cantidad de enlucidos existentes en las piedras y las juntas. La presencia de pátinas de oxalato cálcico puede atribuirse asimismo a los trabajos de conservación antiguos.

La sustitución de elementos de piedra originales (presumiblemente del marmol de San Giuliano) por mármoles de la región "Apuania", fue -y es- el trabajo más habitual en la conservación (6). El mármol de San Giuliano fue empleado en tiempos para los mismos fines, haciendo muy dificil la distinción entre los materiales originales y los sustituidos; también existen varios casos evidentes de haber sido utilizado para reemplazar los bloques de breccia de "Agnano" en descomposición progresiva en la cara interna de la estructura cilíndrica.

En los documentos de archivo puede comprobarse la fecha de algunas de las reparaciones y restauraciones: 4 columnas en 1394 y otras en 1398; más tarde, durante el siglo XVI, fueron reemplazadas 50 columnas.

Actualmente, resultan sustituidas 175 de las 269 columnas existentes y 195 de los capiteles originales.

Una restauración más amplia del monumento se llevó a cabo entre 1798 y 1807 . Amplias zonas de la cara externa del muro en la zona del primer nivel (base) fueron reconstruidas en 1838 al haberse producido una profunda fisura. Posteriores trabajos de restauración se llevaron a cabo en el siglo XIX, como se describe en (16). En 1904, las volutas de las logias fueron reforzadas con grapas metálicas.

Durante la Segunda Guerra Mundial, una ventana de la base, varias columnas del cuarto nivel y la octava cornisa, sufrieron desperfectos, siendo posteriormente reparadas. Recientemente (17) se aplicaron tratamientos urgentes de consolidación con productos químicos en los capiteles y cornisas muy alteradas, pertenecientes a distintos niveles, especialmente en la zona Sur.

Los enlucidos se emplearon, bien como sustitutivo de elementos arquitectónicos o como método directo de reparación de éstos in situ cuando presentaban extensas grietas, rotura o un deterioro máximo (lo que suele ser weak points (grain boundaries and micro-fissures): see also (15).

\section{INTERVENTIONS FOR THE REINFORCEMENT OF THE MASONRY}

Over the centuries protective treatments and maintenance works have been carried out on the Tower which account for the many replaced elements and the plentiful plaster observed on stones or within joints. Also the presence of Ca-oxalate patinas can be attributed to past protective works.

The replacement of original stone elements (presumably San Giuliano marble) by "Apuanian" marbles was and is the most common type of maintenance work for the substitution of damaged or decaying materials (6). San Giuliano marble was also used at times for the same purpose, making it quite difficult to distinguish between replacement and original materials; there are also several evident cases of its use to replace decaying "Agnano" breccia blocks on the internal facing wall of the cylinder masonry.

Archive documents allow the datation of some repair and restoration interventions: 4 columns in 1394 and others in 1398; furthermore, 50 columns were replaced during the XVI century. At present, 175 of the existing 269 columns and 195 of the original capitals result replaced.

An extensive restoration of the monument was carried out from 1798 till 1807. Large parts of the external facing wall at the level of 1st order (base) have been rebuilt in 1838 around a deep fissure. Further restoration works during XIX century are mentioned in (16). Loggias vaults have been reinforced by metal clamps in 1904.

During the 2nd World War a window of the base, a column of the 4th order and the 8th cornice have been damaged and later repaired. Recently (17) urgent consolidation treatments by selected chemicals have been applied to deeply decayed capitals and cornices belonging to various order, expecially on the South side.

Plastering was used either subsequent to the replacement of architectural elements, or as a direct method of repairing elements in situ when damaged by extensive cracking, breakage or heavy decay (events 
bastante común en piedras de baja cohesión interna, como areniscas o brecias). En algunas zonas de enlucido se apreciaron bloques de breccia de "Agnano" deteriorados, así como calcarenita "Panchina" en zonas internas del muro.

Los enlucidos eran de varios tipos, de cal (los más antiguos) o de cemento (los más recientes). Enlucidos de cal o cemento se encontraron en aproximadamente un 5\% de los elementos de las logias, cornisas y la fachada exterior de la base (primer nivel) y del octavo nivel (campanario), mientras que aproximadamente el $15 \%$ de los elementos que configuran la fachada externa del cilindro (desde el $2^{\circ}$ al $7^{\circ}$ nivel) presentan enlucido en algunas de sus zonas. En 1935 se realizaron inyecciones de cemento (aproximadamente 80 toneladas), sobre todo en la zona de los cimientos (Figura 5), y también como relleno del primer nivel del cilindro (base). Su presencia fue detectada por inspección visual y/o por toma de muestras en el núcleo, así como por análisis químicos $\mathrm{y}$ mineralógicos. En algunos casos, la inyección provocó la extrusión del cemento a través de los espacios entre los bloques de piedra, como sugiere la formación de diversas costras encontradas en la caja de la escalera (base del primer nivel).

Las intervenciones llevadas a cabo por el Comité tienen una relación directa con los diversos aspectos patológicos de la estructura: deterioros producidos por la intemperie, biológicos, daños mecánicos (grietas, fisuras, espacios huecos, el material de relleno, separación del material de relleno de la superficie de los muros (18-20). El Proyecto de Restauración (limpieza, protección y conservación de la superficie de las piedras) será llevado a cabo por el "Istituto Centrale del Restauro".

En relación con el refuerzo de la estructura se realizó un nuevo levantamiento (21) con la finalidad de identificar las áreas que precisaban ser localmente reforzadas, por tratarse de un índice de riesgo que se deduce de la combinación de la fatiga y de los daños en las piedras. De esta manera se evitarán todas las intervenciones que pudieran ser inútiles o perjudiciales.

Se pudo constatar que la zona más crítica (aquélla que había sufrido mayor fatiga) se localiza en la zona sur de la primera cornisa (Figura 6), donde se reduce la sección transversal de la fábrica, y existe una amplia apertura debida a la presencia de la escalera interior. Sin embargo, la cara externa del muro, la más pesada (normalmente, la fatiga por compresión llega a alcanzar, aproximadamente, 8-10 MPa) descansa directamente sobre el material de relleno inferior. particularly common in those stone types with rather weak cement, such as sandstones or breccias). Several zones of plastering were observed on blocks of decaying "Agnano" breccia and "Panchina" calcarenite in the internal facing wall.

The plaster contains different types of mortar that are either lime (older) or cement (more recent) based. Lime or cement plaster was found on about $5 \%$ of the loggia elements (cornices and the outer façade of the $1^{\text {st }}$ order/base, and 8th order/bell-chamber), while about $15 \%$ of the elements making up the external cylinder façade (from the $2^{\text {nd }}$ to $7^{\text {th }}$ order) have plastered zones. Furthermore, in 1935 massive cement injections (about 80 tons) have been implemented, mainly within the foundations (Figure 5), also involving the masonry "infill" (1 $1^{\text {st }}$ order/base of the cylinder); its presence has been pointed out both by direct visual inspection and/or core sampling, and by chemical and mineralogical analyses. In some cases, the injection may also have caused the extrusion of cement from between stone blocks, as suggested by the composition of some crusts found in the stairwell (1st order/base).

The interventions implemented by the Committee are linked to the various pathological aspects of the masonry structure: weathering-biological decay and mechanical damage (cracks, fissures, voids within the "infill" material, detachments of the "infill" material from facing walls) (18-20). Cleaning, protection and conservation of stone surfaces will be matter of a separate Restoration Project to be carried out by the "Istituto Centrale del Restauro".

Dealing with the reinforcement of the masonry structure, a new kind of mapping (21) was conceaved in order to identify the areas in which local strengthening is needed, by means of a "risk index" deduced from the combination (integration) of stress state and degree of stone damage. Therefore, useless and detrimental interventions are avoided.

It was recognized that the most critical zone (most severely stressed) is located at the level of the 1st cornice/South side (Figure 6), where the crosssection of the masonry reduces, and a large opening exists due to the presence of the inner staircase. Moreover, the heavely loaded external facing wall (currently, the compression stress is reaching about 8-10 MPa) rests directly on the underneath "infill" material. 


\section{Sección transversal de la Torre de Pisa con la trayectoria de esfuerzo en la primera cornisa de la zona Sur}

Cross-section of Pisa Tower at first cornice stress trajectories on south side



Figura 6.- Zona más critica en la estructura de mamposteria ( $1^{\text {a }}$ cornisa, lado Sur).

Figure 6.- Most "critical" zone of the masonry structure (I ${ }^{\text {st }}$ cornice, South side).

Las inspecciones por sonda de radar, endoscopía visual y por TV (Figura 7), revelaron la existencia de un material de relleno con grandes espacios huecos (hasta un $20-25 \%$ en volumen), pérdida también de mortero entre los fragmentos de cascotes y separación desde las caras vistas de los muros.

En lo que concierne a la integridad estructural, la sección transversal más crítica, fue temporalmente tensada en 1992 (Figura 8) por cables de acero posttensionados, colocados como flejes alrededor de la cara externa del muro en la primera logia. Estos cables ejercen una ligera precompresión circular que previene el pandeo de las piedras, y mejora la resistencia a la compresión vertical. Asimismo, en el hueco de la escalera se colocaron varios armazones metálicos.

Se realizaron intervenciones estructurales permanentes donde el nivel de riesgo lo requería, con el fin de aumentar la resistencia del cuerpo de la fábrica por medio de un incremento de la resistencia a compresión, y también para obtener una mayor cohesión entre los muros externos y el material de relleno. Dichas intervenciones consisten en la combinación de las siguientes actuaciones (22).

i) precompresión horizontal del material de relleno y unión por tensión de las dos caras de los muros a través de barras de acero tensadas;
Radar sounding, visual and TV endoscopic inspections (Figure 7) revealed the existence within the "inflll" material of large voids (until 20-25\% by volume), lack of mortar between rubble fragments and detachments from facing walls.

The concern for the structural integrity in the most critical cross-section of the masonry has been temporarely lowered by post-tensioned high tensible steel tendons put in place in 1992 (Figure 8). The unbounded strands, placed as hoops around the external facing wall at the 1st loggia, exert a light circumferential precompression which prevents buckling of the stones, and improves the strenght to vertical compression. Moreover, some metallic frames have been set up inside the staircase.

Permanent structural interventions applied where the "risk intex" requires their need to improve the resistance of the masonry body by an increase of the compressive strength and to get a better connection between facing walls and "infill" material, consist of the combination of different means (22).

i) horizontal precompression of the "infill" material, and tensile connection of the two parallel facing walls by means of tensioned stainless steel bars; 


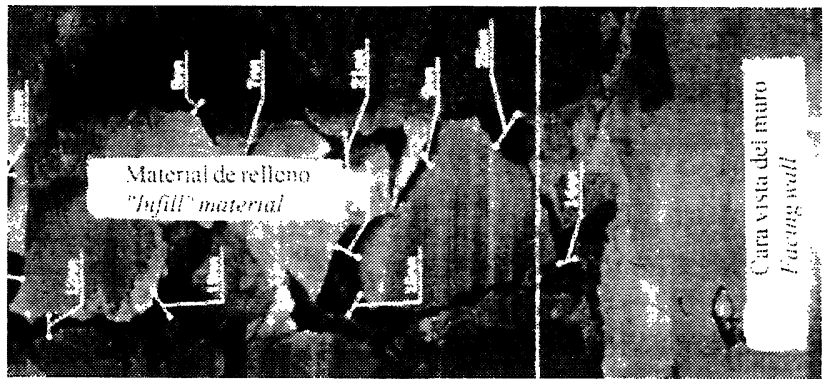

Inspección por TV TVinspection

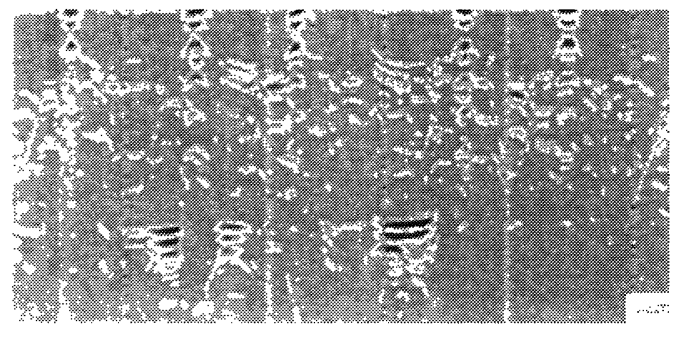

Sondeo por radar en el material de relleno Radar sounding of "infill" material

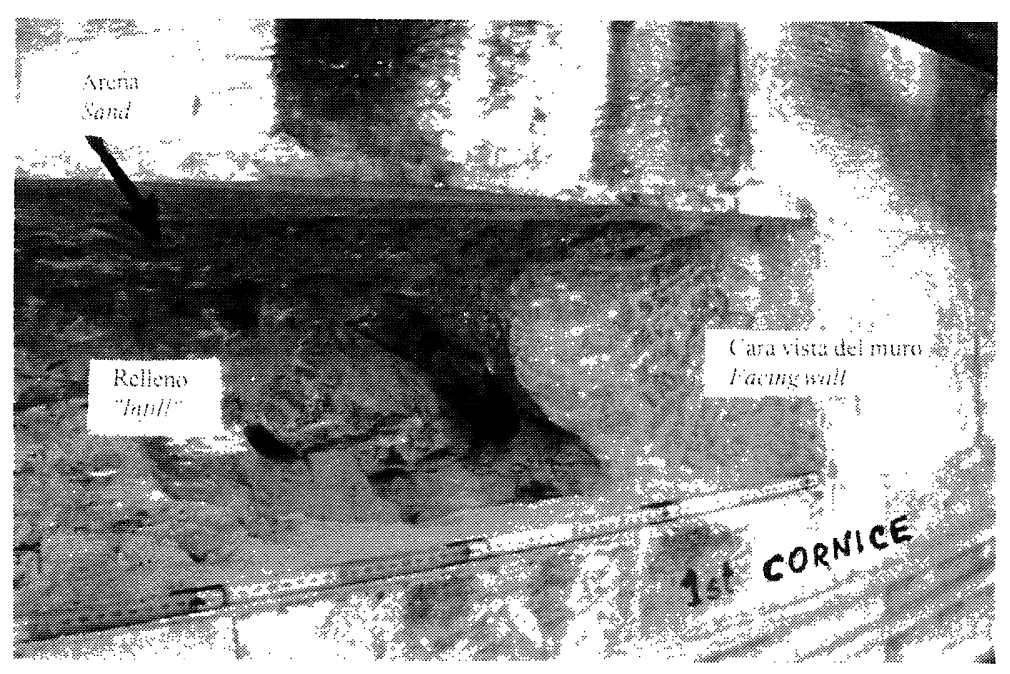

Inspección visual a nivel de la $1^{\circ}$ comisa

$V$ isual inspection at the level of $I^{\text {st }}$ cornice
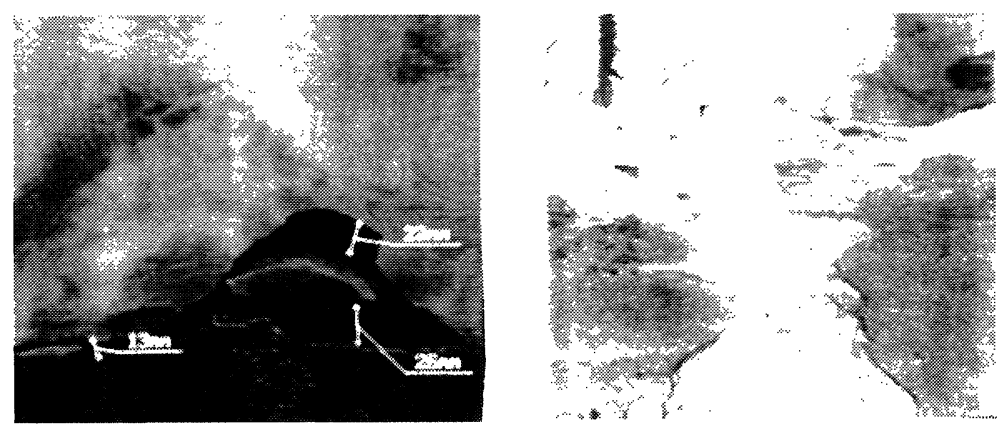

Inspección por TV / TV inspection

Antes / Prior

Después / After

Test de lechada / Grouting test

Figura 7.- Inspección interna de la estructura de la mampostería.

Figure 7.- Inner inspection of the masonry structure. 


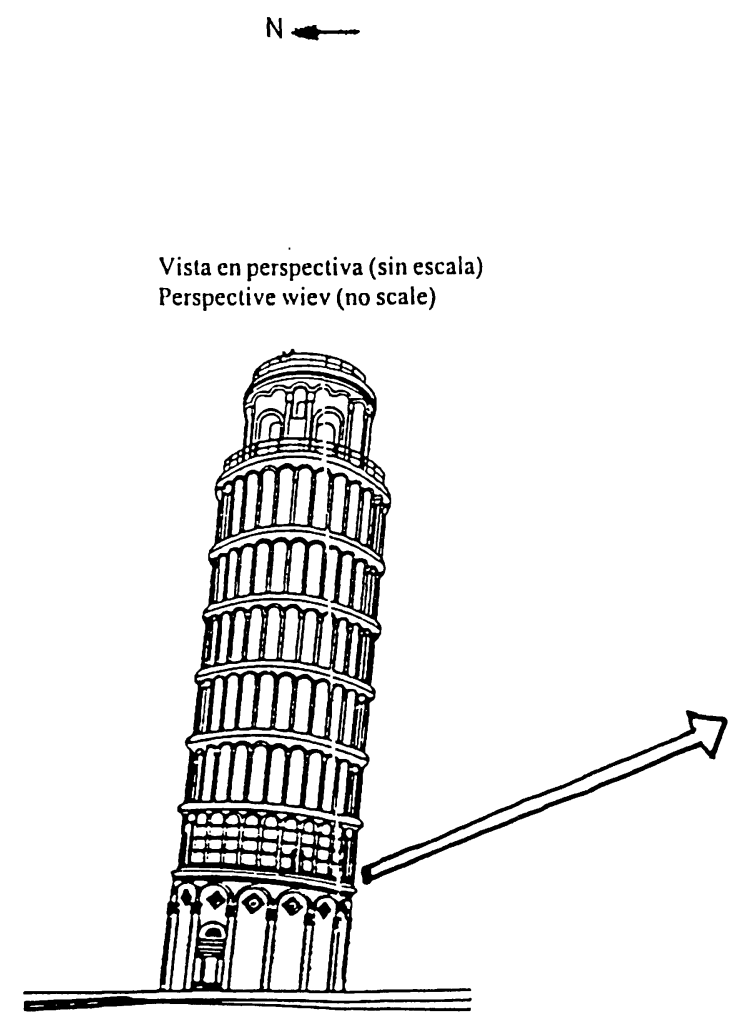

ii) inyección del material de relleno y su unión con los bloques de mármol de las caras de los muros.

Las barras de acero, dispuestas transversalmente en el cuerpo de la Torre, son capaces de equilibrar las tensiones creadas por las grietas verticales y reducir el esfuerzo de compresión. Las barras de $16 \mathrm{~mm}$ de diámetro (aplicadas, incluso, con una longitud de 4,5 $\mathrm{m})$ fueron realizadas con un acero inoxidable de alta resistencia, tensionadas de forma tal que se pudiera crear una compresión radial y presionar las caras exteriores de los muros contra el material de relleno con el fin de aprovechar su contacto. Esta conexión radial es un control eficiente contra el pandeo ya que se basa en un concepto de resistencia a la fuerza axial por reacción paralela al eje, evitando así, por tanto, la desintegración.

Las barras de acero empleadas son de alta durabilidad (ausencia de corrosión) y reversibles, porque se evita cualquier relleno de los agujeros por inyección y anclajes químicos. Los anclajes mecánicos permiten cambiar y sustituir las barras en el futuro. Se han efectuado ensayos de laboratorio para desarrollar un nuevo sistema de anclaje que elimine la aparición de

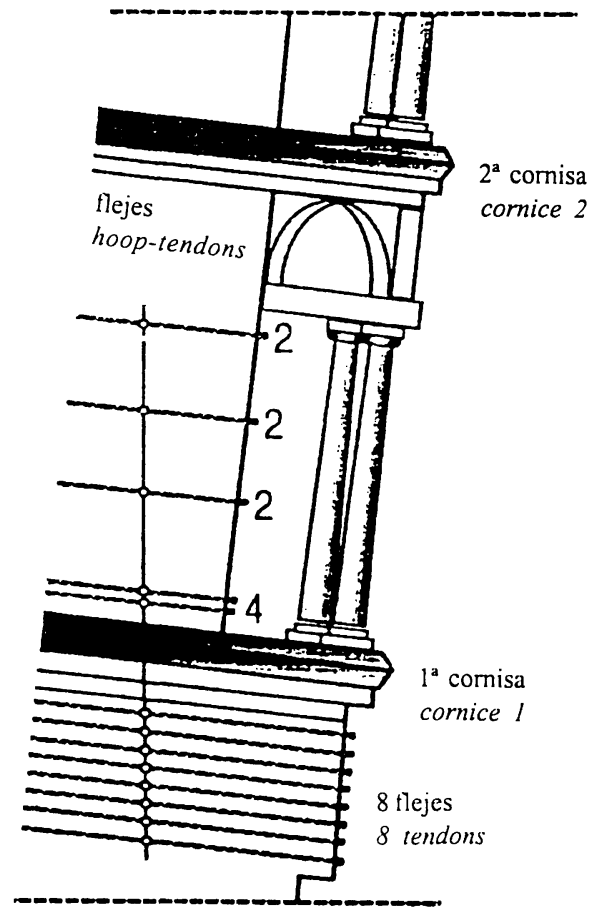

Figura 8.- Refuerzo temporal de la sección más "débil" de la estructura de mamposteria con la ayuda de flejes de acero.

Figure 8.- Temporary strengthening of the "weakest" section of the masonry structure by steel hoops.

ii) grouting of the "infill" material and of its contact with the marble blocks of the facing walls.

The steel bars, disposed trasversally within the masonry body, are able to equilibrate the splitting tensile stresses which create the vertical cracks, and to reduce the compressive stress. The $16 \mathrm{~mm}$ diameter bars (even applied on a lenght of $4.5 \mathrm{~m}$ ) are made of high tensile stainless steel, and are tensioned in such a way to create a readial precompression, thus pressing the facing walls against the "infill" material and improving their contact; such radial connection is an efficient restraint against buckling because it is based on the concept of resisting the axial force by reaction parallel to the axis, and therefore avoiding splitting actions.

The employed stell bars will have long durability (absence of corrosion) and are reversible because it is avoided any grouting of the holes and chemical anchorages: mechanical anchorings allow the bars to be removed and replaced in the future. A newly developed anchoring system, previously tested in laboratory, avoids appearance of steel plates on the 
chapas de acero en la cara externa de los muros de mármol (el anclaje se sitúa adentro de los bloques de mármol de la fachada externa).

Investigaciones previas han conducido a la realización de una mezcla de inyección con una adecuada composición, granulometría y propiedades reológicas y mecánicas (23) de modo que se impida el goteo de agua, ataque por sulfatos y elementos alcalinos, $\mathrm{y}$ conseguir una baja presión de inyección (23).

El cemento utilizado (cemento "microlito, granulometría D-98 $\leq 10 \mu \mathrm{m}$ )tenía la siguiente formulación: clinker de $\mathrm{Fe}=81,5 \%$, humo de sílice $=$ $14,5 \%$, anhidrita $=4 \%$, un $3 \%$ de un aditivo dispersante (MAC-Rheobuilt 1000) y agua (relación agua/cemento $=1: 1$ ). El material resultante tenía las siguientes características: bajo contenido en $\mathrm{Na}_{2} \mathrm{O}$ equivalente $(0,53 \%)$, resistencia al ataque por sulfatos (Ansett test), adecuada densidad, viscosidad, coeficiente de presión, capacidad de penetración, tiempo y límite de inyección, tiempo de fraguado, estabilidad a la decantación, cohesión y resistencia a la compresión y a cortante. Además, la suspensión de la inyección de lechada es inyectable a presiones bajas $(<0,4 \mathrm{~atm})$. El clínker de $\mathrm{Fe}$ está constituido principalmente por $\mathrm{C}_{3} \mathrm{~S}$ y material vítreo-amorfo; la presencia de otras fases también fue identificada por difracción de Rayos $\mathrm{X}$ : $\mathrm{C}_{2} \mathrm{~S}, \mathrm{C}_{4} \mathrm{AF}\left(+\mathrm{C}_{2} \mathrm{~F}\right), \mathrm{CaO}\left(\right.$ ?), $\mathrm{MgO}\left(\right.$ ?), $\mathrm{K}_{2} \mathrm{SO}_{4}$ (no), $\mathrm{C}_{3} \mathrm{~A}(\mathrm{no}), \mathrm{Na}_{2} \mathrm{SO}_{4}$ (no), $\mathrm{CaSO}_{4}$ (no). La composición química y de fases de este cemento se presenta en la Tabla 4. external marble facing wall (the anchor is located inside the marble blocks of the external facing wall).

Preliminary investigations have been carried out for realizing a grouting admixture with appropriate composition, granulometry (23), rheological and mechanical properties to avoid "bleeding" and sulphate-alkali attack, and to achieve low injection pressure (23).

A formulation ("microlite" cement: granulometry: D-98 $\leq 10 \mu \mathrm{m}$ ) consisting of Fe-clinker $=81.5 \%$, silica "fume" $=14.5 \%$, anhydrite $=4 \%$, added with $3 \%$ of a dispersant (MAC-Rheobuilt 1000) and water $(C / W$ ratio $=1: 1)$ resulted suitable for the aimed purposes: low $\mathrm{Na}_{2} \mathrm{O}$ equivalent $(0.53 \%)$, resistent to sulphate attack (Ansett test), satisfactory density, viscosity, pressure filtration coefficient, penetration capability, groutability limit and grouting time, setting time, stability to decantation, cohesion, compressibility and shear strength. Furthermore the grouting suspension is injectable at a pressure lower than 0.4 atmosphere. Fe-clinker is mainly constituted of $C_{3} S$ and amorphous-vitreous matter; the presence of other phases has also been checked up by $X$-ray diffractometry: $\mathrm{C}_{2} S, \mathrm{C}_{4} A F\left(+\mathrm{C}_{2} F\right), \mathrm{CaO}$ (?), $\mathrm{MgO}$ (?), $\mathrm{K}_{2} \mathrm{SO}_{4}$ (no), $\mathrm{C}_{3} \mathrm{~A}(\mathrm{no}), \mathrm{Na}_{2} \mathrm{SO}_{4}$ (no), $\mathrm{CaSO}_{4}$ (no). Its chemical composition and derived phases are (Table 4).

TABLA 4 (TABLE 4)

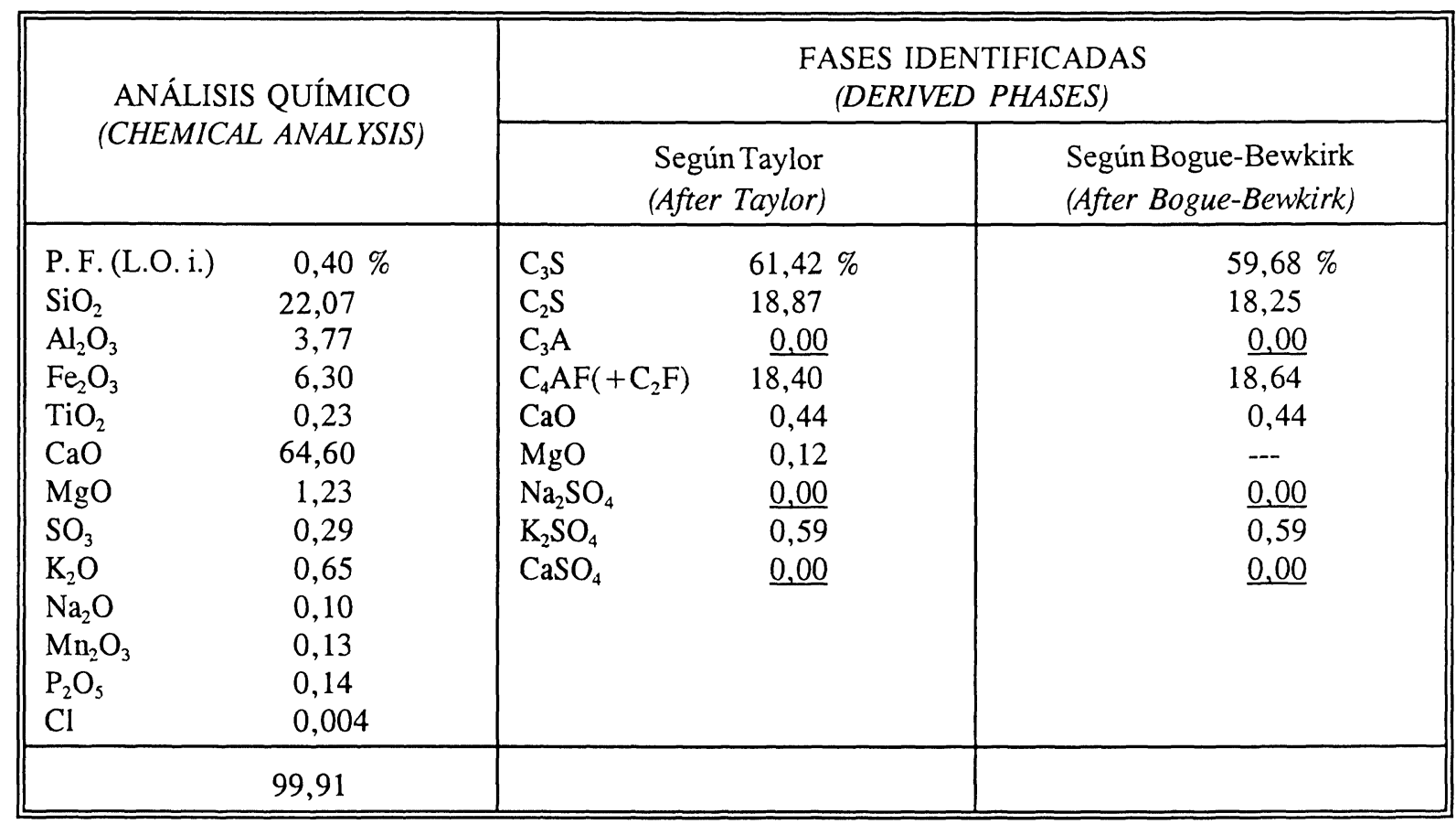


El humo de sílice es, mayoritariamente, una sílice amorfa, con trazas de cuarzo y $\mathrm{SiC} ; \mathrm{SiO}_{2}=95 \%$, $\mathrm{Ca} 0=1 \%, \mathrm{Al}_{2} \mathrm{O}_{3}=0,5 \%, \mathrm{Fe}_{2} \mathrm{O}_{3}=0,2 \%, \mathrm{TiO}_{2}$ y $\mathrm{Mg} 0$ ausentes, P.F. $=3,3 \%$.

El humo de sílice reduce la carbonatación y disminuye la porosidad, aumentando la densidad de los sistemas cementicios, impidiendo la penetración de agentes agresivos.

Ensayos preliminares in situ con estas inyecciones (24) demostraron que se había producido una mejora significativa en el material de relleno: sellado de poros y adherencia a las caras vistas de los muros, según inspección llevada a cabo por TV endoscópica (Figura 7); produciéndose al mismo tiempo un aumento de la resistencia. La principal intervención en la zona más débil de la estructura (primera cornisa) se inició en julio de 1999, y se completará en la primavera de 2000 , este sellado se extenderá también al tercer nivel, donde se colocó el sistema temporal de cableado (Figura 9) y además a la base (primer nivel).

Los trabajos de excavación (subsidencia controlada) que están realizados en el suelo por debajo de la zona Norte de los yacimientos con el fin de reducir la inclinación de la Torre
Silica "fume" is mainly amorphous silica, with traces of quartz and $\mathrm{SiC} ; \mathrm{SiO}_{2}=95 \%, \mathrm{CaO}=1 \%$, $\mathrm{Al}_{2} \mathrm{O}_{3}=0.5 \%, \mathrm{Fe}_{2} \mathrm{O}_{3}=0.2 \%, \mathrm{TiO}_{2}$ and $\mathrm{MgO}$ absent, l.o.i. $=3.3 \%$.

Silica fume reduces the potentiality of carbonatation and gives rise to less-porous and denser systems, thus hindering the penetration of damaging agents.

Preliminary in-situ grouting tests (24) showed a satisfactory improvement of the "infill" material: filling of voids, and adherence to facing walls, as inspected by endoscopic TV views (Figure 7); moreover, increase of strength. The main intervention concerning the weakest zone of the masonry structure ( $1^{\text {st }}$ cornice) is being implemented from july 1999 and it will be completed in spring of 2000; the grouting will be also extended to the $3^{\text {rd }}$ order where the temporary "stay cable" system is connected with the masonry body of the Tower (Figure 9), and to the base ( $1^{\text {st }}$ order).

The already being implemented reduction of the Tower inclination by soil excavation (controlled subsidence) under the North side of the foundations (for improving the stability of the foundations/

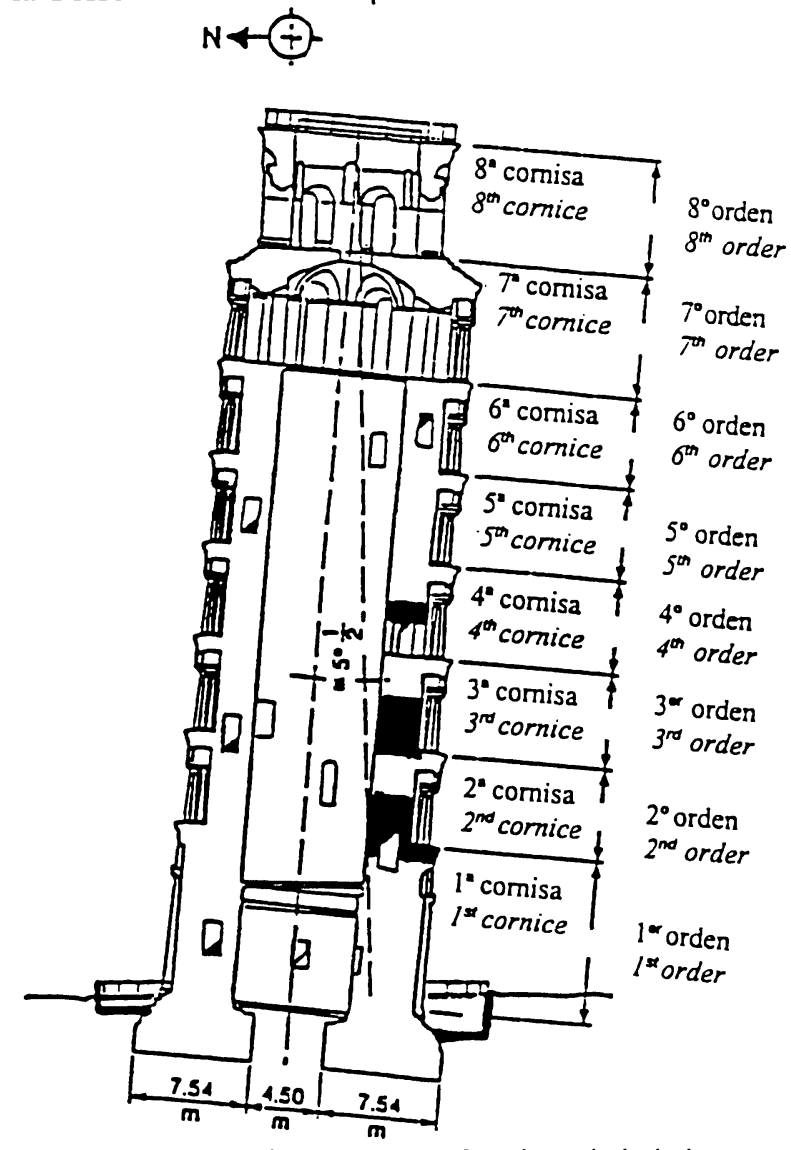

Figura 9.- Zonas dañadas ( $\square$ ) de la estructura de mamposteria reforzada con lechada de cemento y barras de acero.

Figure 9.- Damaged zones (-) of the masonry structure reinforced by cement grouting and steel bars. 
también llegaron a reducir la fatiga de la carga en la zona Sur de la estructura de la fábrica, mejorando así la estabilidad del sistema de cimiento/subsuelo.

La reducción prevista es de $0,5^{\circ}$, lo que supondrá unos $30 \mathrm{~cm}$ de saliente; será como recuperar 250 años en la vida de la Torre, ya que el incremento de inclinación en los últimos tiempos suponía, aproximadamente, unos $1,2 \mathrm{~mm}$ por año de media. subsoil system) will also reduce the loading stress at the South side of the masonry structure.

The planned reduction is about $0.5^{\circ}$, i.e. overhang will belowered of $30 \mathrm{~cm}$. It will recover about 250 years back of the Tower life, taking into account that recent tilting rate was $1.2 \mathrm{~mm}$ per year (average).

\section{BIBLIOGRAFÍA}

(1) O. Banfi, P. Sanpaolesi, S. Casadio: II Campanile di Pisa. Una cittá e la sua torre. Pacini, 1997.

(2) Ministero Lavori Pubblici: Ricerche e studi su la Torre pendente di Pisa e i fenomeni connessi alle condizioni di ambiente. Commissione per il consolidamento della Torre pendente di Pisa, vol. I, II e III, Ist. Geografico Militare, Firenze, 1971.

(3) A. Gherardesca: Sulla pendenza del Campanile della Primaziale Pisana, Considerazioni. Nistri, 1838.

(4) M. Franzini, L. Leoni, F. Sartori, F. Veniale: Analisi composizionale dei materiali (pietre e malte) utilizzati per la construzione e per opere di restauro della Torre di Pisa, e dei loro prodotti di degrado: propedeutica al progetto di restauro materico, architettonico e strutturale. Rapporto Interno. Comitato Int. Salvaguardia Torre di Pisa, 1994.

(5) F. Veniale: Building materials of the "leaning" Tower of Pisa: stones, mortars and their decay by-products. With the collaboration of M. Franzini, L. Leoni, M. Lezzerini, F. Sartori: Dip. Science della Terra, Univ. Pisa; S. Lodola, Dip. Scienze della Terra, Univ. Pavia in Workshop "The restoration of the leaning Tower of Pisa: present situation and perspectives", Pisa 1999. Pre-prints. .

(6) S. Lodola, F. Veniale: Individuazione dei diversi tipi di marmi Apuani utilizzati per interventi di sostituzione di elementi architettonici. Rapporto Interno, Comitato Int. Salvaguardia Torre di Pisa, 1998.

(7) M. Franzini, L. Leoni, F. Sartori, F. Veniale: "Mappatura sistematica dei litotipi della Torre di Pisa. Rapporto Interno, Comitato Int. Salvaguardia Torre di Pisa, 1994.

(8) M. Lezzerini: Studio chimico, mineralogico, petrografico, fisico e meccanico di malte antiche (in edifici storici della città di Pisa, compresa la Torre "pendente"). Finalizzazione alla loro conservazione e restauro. Tesi dottorato Science della Terra, Univ. Pisa, 1996.

(9) A. M. Romanini: Analisi storica della construzione e dei restauri della Torre di Pisa. Rapporto Interno, Comitato Int. Salvaguardia Torre di Pisa, 1995

(10) M. Franzini, L. Leoni, F. Sartori, F. Veniale: The leaning Tower of Pisa-Occurrence and distribution of the masonry decay byproducts. Sci. Tech. Cultural Heritage, 6, 1997, pp. 135-144.

(11) M. Cordaro, M. D'Elia: Analisi degli inquinanti atmosferici nell 'ambiente circostante la Torre. ISMES. Rapporto Interno, Comitato Int. Salvaguardia Torre di Pisa, 1996.

(12) D. Camuffo, M. Cordaro, M. D'Elia: Torre di Pisa - Studio di analisi del microclima e delle interazioni ambiente-manufatto. Rapporto Interno, Comitato Int. Salvaguardia Torre di Pisa, 1995.

(13) D. Camuffo, M. Cordaro, M. D'Elia: Studio per la individuazione dei percorsi di percolamento interno alla Torre mediante traccianti. Rapporto Interno, Comitato Int. Salvaguardia Torre di Pisa, 1999.

(14) M. Vendrell-Saz, M. García-Valles, J. Molera, F. Veniale: Crusts, patinas and surface deposits on building stones of the leaning Tower of Pisa. Proc. 4th Int. Symp. Conservation of Monuments in the Mediterranean Basin, Rhodos, 1, 1997, pp. 173-182.

(15) M. Monte, M. D’Elia, M. Cordaro: Studio delle alterazioni di natura biologica sulle superfici della Torre di Pisa. Rapporto Interno, Comitato Int. Salvaguardia Torre di Pisa, 1995.

(16) L. Lenzi: I restauri attocenteshi del Campanile pendente e le problematiche presenti. Pisa Oggi, 1990, pp. 16-54.

(17) S. Vedovello, M. D'Elia, M. Cordaro: Studio delle condizioni di stabilità delle zone aggettate dell 'elevato della Torre e risanamento della parti pericolanti, Rapporto Interno, Comitato Int. Salvaguardia Torre di Pisa, 1995.

(18) G. Macchi: Indagini strutturali sulla Torre di Pisa. Rilievo quantitativo della patologia strutturale. Rapporto Interno, Comitato Int. Salvaguardia Torre di Pisa, 1993.

(19) G. Macchi: Indagini strutturali sulla Torre di Pisa. Riesame delle endoscopie TV dei carotaggi ISMES 1986, Rapporto Interno, Comitato Int. Salvaguardia Torre di Pisa, 1994.

(20) Ministero Lavori Pubblici: Indagini sullo stato delle murature e dei terreni di fondazione della Torre pendente di Pisa, preliminari alla progettazione esecutiva delle opere di consolidamento definitivo. RODIO, Rapporto Interno, Comitato Int. Salvaguardia Torre di Pavia, 1986.

(21) G. Macchi: Mappatura combinata delle tensioni massime e delle valutazioni non-distruttive della qualità della muratura della Torre di Pisa, Rapporto Interno, Comitato Int. Salvaguardia Torre di Pisa, 1995.

(22) G. Macchi: Progetto di rinforzo strutturale della muratura della Torre di Pisa. Iniezioni, barre e tasselli, Lab. Prove Materiali c Strutture, Dip. Meccanica Strutturale, Fac. Ingegneria, Univ. Pavia Rapporto Interno, Comitato Int. Salvaguardia della di Pisa, 1998.

(23) G. Macchi, F. Veniale: Prove di qualificazione della miscela di iniezione a base di cemento ferrico e fumi di silice, Rapporto Interno, Comitato Int. Salvaguardia Torre di Pisa, 1995.

(24) G. Macchi: Prove di iniezioni cementizie per il reinforzo della muratura, Rapporto Interno, Comitato Int. Salvaguardia Torre di Pisa, 1995. 